\title{
The Role of Counsel in Civil Commit- ment Proceedings: Emerging Problems
}

\author{
Thomas R. Litwack*
}

\section{I \\ The Right to Counsel and the Requirements of Meaningful COUNSEL: Beginnings OF A NeW LEgAL Doctrine}

Recent years have seen increasing judicial ${ }^{1}$ and legislative ${ }^{2}$ recognition that individuals subject to involuntary hospitalization should have a right to counsel, perhaps even court-appointed counsel. But the notion of a "right to counsel" has not yet been fully developed and articulated. The eventual dimensions of this right will thus depend on how it is defined, in practice as well as in theory. Unfortunately, even in those states where a right to appointed counsel is rec-

* B.A., Dartmouth College, 1964; Ph.D., New York University, 1972; J.D., Now York University, 1974; Assistant Professor of Psychology, John Jay College of Criminal Justice, The City University of New York.

1. In re Barnard, 455 F.2d 1370 (D.C. Cir. 1971); Heryford v. Parker, 396 F.2d 393 (10th Cir. 1968); Lessard v. Schmidt, 349 F. Supp. 1078 (E.D. Wis. 1972), vacated and remanded for more specific order, 94 S. Ct. 713 (1974); Dixon v. Attorney General, 325 F. Supp. 966 (M.D. Pa. 1971); Denten v. Commonwealth, 383 S.W. $2 \mathrm{~d} 681$ (Ky. 1964); People ex rel. Woodall v. Bigelow, 20 N.Y.2d 852, 231 N.E.2d 777, 285 N.Y.S.2d 85 (1967); People ex rel. Rodgers v. Stanley, 17 N.Y.2d 256, 217 N.E.2d 636, 270 N.Y.S.2d 573 (1966). See also In re Hnat, 250 So. 2d 890 (Fla. 1971); McCorkle v. Smith, 100 N.J. Super. 595, 242 A.2d 861 (App. Div. 1968); State v. Collman, 9 Ore. App. 476, 497 P.2d 1233 (Ore. Sup. Ct. 1972).

The Heryford court relied substantially on the reasoning of $l n$ re Gault, 387 U.S. 1 (1966), which held that juveniles faced with delinquency proceedings and the possibility of incarceration have a due process right to counsel. 396 F.2d at 394-96. The Lessard court, in addition to adopting an expansive view of the right to counsel, noted that the "constitutional requirement of representative counsel" could not be satisfied by the appointment of a guardian ad hitem because "the guardian does not view his role as that of an adversary counsel and thus cannot take the place of counsel unless his role is restructured." 349 F. Supp. at 1097.

2. See Brakel \& Rock, The Mentaliy Disabled and the Law 54 (1971). Compare an earlier version of the same report, LINDMAN \&.. MCINTYRE, THE MENTALly DisABLED AND tHE LAW 29 (1961).

As of 1971,42 jurisdictions provided by statute for the right to be represented by an attorney or guardian ad htenl at civil commitment proceedings. Only 24 jurisdictions, however, provided for the appointment of counsel if the paticnt had none. BrAHEL \& RocK, supra, at 54; Cohen, The Function of the Attorney and the Commitment of the Mentally Ill, 44 Texas L. Rev. 424, 437, 460-66 (1966) [hereinafter cited as Cohen]. 
ognized, the right is largely an empty one; with few exceptions, patients receive considerably less than adequate legal assistance.

For example, indefinite commitment hearings are conducted in Texas under a statute that has been labeled "a modern mental health code which, on a formal basis, ranks with the very best in this country."3 But, according to this same commentator, the hearing often takes place far froin the patient's home. The "attorney ad litem" is chosen from among young attorneys and is appointed to serve for that day only. The attorney rarely sees the patient before the hearing. Few patients appear at their own hearings. The judge typically asks two physicians who have recently "examined" the patient whether they believe he should be committed. The doctors answer "yes." The attorney rarely asks questions of the physicians; there is no exploration of such issues as prognosis, alternative nethods of treatment, or likelihood of danger to self and others. ${ }^{4}$

Another report describes similar defects in the administration of psychiatric justice in Arizona. ${ }^{5}$ Under the Arizona statute, if the patient cannot afford retained counsel, an attorney must be appointed before the hearing. However, in some cases attorney and patient do not meet until the case is called; even when they do ineet before the hearing, the patient is often too heavily medicated to be of any assistance. $^{6}$ Many appointed attorneys indicate that they would prefer to spend more time preparing their cases but that the small fee for each case precludes even cursory investigation. In one county, appointed attorneys merely ask petitioning witnesses whether the statements in the petition for commitment are true, and then ask the testifying psychiatrists for their opinion of the patient. Evidence is seldom offered - or requested-to support the conclusions in the petition. Witnesses are rarely cross-examined, and little is asked of the psychiatrists other than their conclusions and recommendations. ${ }^{7}$ Attorneys rarely ask

3. Cohen, supra note 2 , at 425 .

4. Id. at 427-31. Not only does the attorney perform merely pro forma duties at the hearing, but he or she engages in no pre- or post-hearing activities such as consulting with the patient's physician, searching for alternatives to hospitalization, or checking to see that the client, if committed, receives adequate treatment. Indeed, the statute imposes no pre-hearing duties on the attorney (nor, however, any limitations). Cohen describes a similarly "silent and 'roleless" attitude on the part of court-appointed attorneys in Colorado. Id. at 440-41.

5. Project: The Administration of Psychiatric Justice: Theory and Practice in Arizona, 13 ARtz. L. Rev. 1 (1971) [hereinafter cited as Project].

6. Id. at $32-35,54$.

7. In another county, the public defender serves as the patient's counsel and does ask some questions concerning the basis of the diagnosis and recommendations. However, "the preparation and participation provided by the public defender does not begin to approximate acceptable standards of advocacy." Id. at 42 . If the examples cited are at all representative, counsel in Arizona could be much more active in clarify- 
what the basis for commitment is-dangerousness to self, to other persons, or to property-or whether alternatives to involuntary commitment are available. ${ }^{8}$ Legal assistance which does not uncover such information is of very limited value.

The Arizona and Texas statutes-typical of those that create a right to appointed counsel-leave it to the organized bar, or to the appointed attorneys themselves, to develop their roles according to their own lights, though presumably guided by legal tradition and the Canons of Professional Ethics. A brief review of the Texas and Arizona experience, however, shows this reliance to be unjustified. Because a right to counsel for the involuntarily committed has been recognized only recently, lawyers who represent such patients have little tradition on which to rely. Commitment hearings differ significantly from other kinds of litigation, yet few attorneys develop expertise in this area of the law because of the infrequency with which they are called. Usually, there is no experienced source of advice available to appointed attorneys. Nor is the typical county judge likely to demand more than perfunctory representation. ${ }^{0}$ Overall, this high degree of inexperience, combined with the limited temporal and financial resources of appointed attorneys, results in little more than pro forma representation of the allegedly mentally ill.

How can adequate representation be achieved? This Article will explore answers to this question by identifying the features of an adequate system of representation and by describing some of the difficulties with which any such system must contend. The exposition will proceed through a critical examination of a state system that represents one of the more comprehensive-and successful-attempts to

ing, through questioning, what the patient did and its significance. See id. at 43-50. For examples of better representation, see ZISKIN, CopING WITH PSYCHIATRIC AND PSYchological TestimoNy 205-79 (1970) [hereinafter cited as Ziskin]; Kumasaka \& Gupta, Lawyers and Psychiatrists in the Court: Issues on Civil Commitment, 32 MD. L. Rev. 6, 19-31 (1972) [hereinafter cited as Kumasaka \& Gupta].

8. Project, supra note 5, at 54.

9. For a recent and comprehensive survey and critique of a number of other systems of representation for individuals allegedly in need of involuntary hospitalization, see Andalman \& Chambers, Effective Counsel for Persons Facing Civil Commitment: A Survey, a Polemic, and a Proposal, 45 Miss. L.J. 43 (1974) [hereinafter cited as Andalinan \& Chambers].

Given the lack of funds usually provided by the states to pay appointed counsel, one may wonder whether the states are not getting exactly the type of representation that they want for their patients.

The effectiveness of counsel at a commitment hearing will depend heavily on his efforts prior to the proceedings. The compensation for appointed counsel in Arizona is so grossly inadequate that attorneys are . . . discouraged from investigating facts, preparing a defense, exploring possible alternatives to commitunent, and seeking outside psychiatric opinions.

Project, supra note 5, at 55. 
provide meaningful assistance to mental patients, the Mental Health Information Services of New York.

II

\section{The Mental Health Information Service}

The Mental Health Information Service ${ }^{10}$ (MHIS) was established by statute in 1964 and began operation in 1965 . The statute provides for a separately administered MHIS in each of the state's four judicial departments. The staffing of the MHIS is not specified in the statute and, as a result, varies considerably from one department to another. In the First and Second Departments the MHIS staff is composed largely of attorneys; in the Third and Founth Departments, of social workers and former probation officers. At Bellevue Hospital in New York City, where the author conducted extended observations of MHIS work, the staff consists of five attorneys, one social worker and one secretary.

The statutory duties of the MHIS are limited to reviewing all admission and retention proceedings for procedural irregularities; informing all patients of their rights; and, at judicial proceedings, providing the court with a report containing "all relevant information as to the patient's case."11 The statute, however, also permits the MHIS to provide such "services to patients . . . as may be required by . . . the regulation of ... the appellate division of each department."12 Pursuant to this provision, only the First Department has assigned MHIS attorneys to act as counsel to hospitalized imdividuals throughout the commitment process.

In New York State "any person alleged to be mentally ill and in need of involuntary care and treatment may be retained at a suit-

10. For descriptions of and comment upon the Mental Health Information Service, see Andalman \& Chambers, supra note 9, at 64-72; Broderick, Justice in the Books or Justice in Action: An Institutional Approach to Involuntary Hospitalization for Mental Illness, 20 CATH. U.L. REv. 547, 620-32 (1971) [hereinafter cited as Broderick]; Gupta, New York's Mental Health Information Service: An Experiment in Due Process, 25 RutGers L. Rev. 405 (1971) [hereinafter cited as Gupta]; Kumasaka, The Lawyer's Role in Involuntary Commitment-New York's Experience, MH [formerly Mental Hygrene], Spring 1972, at 21; Note, New York Mental Health Information Service: A New Approach to the Hospitalization of the Mentally Ill, 67 CoLum. L. Rev. 672 (1967) [hereinafter cited as A New Approach]. See also N.Y. Mental HYGIENE LAW $\$ 29.09$ (MCKinney 1973).

11. N.Y. Mental Hygrene LAW $\$ 29.09$ (b) (McKinney 1973). The statute originally applied only to "involuntary patients," but in In re Buttonow, 23 N.Y.2d 385, 244 N.E.2d 677, 297 N.Y.S.2d 97 (1968), the Court of Appeals held that equal protection requires that "voluntary" patients be afforded the same assistance.

12. N.Y. Mental Hygiene LAW $\$ 29.09$ (b) (4) (McKinney 1973). For a fuller discussion of the differences among the four judicial departments, see Broderick, supra note 10, at 624-26; Gupta, supra note 10, at 417-19. 
able hospital upon the certification of two physicians."13 The patient, however, has a right to challenge his or her commitment at a judicial hearing shortly thereafter. ${ }^{14}$ As a result, MHIS attorneys usually meet with their chents after their commitment but before any court hearing.

The New York Mental Hygiene Law requires that patients be informed of their right to MHIS assistance, as well as their other statutory rights, by two forms of written notice: a printed sheet given to the patient "immediately upon his admission" to a hospital or his "conversion to a different status,"15 and a poster placed "throughout the hospital where such notice will be conspicuous and visible to all patients."16 Some patients are informed of the Service by MHIS personnel themselves. Others learn about it from the hospital staff or from fellow patients. ${ }^{17}$ Still others find out by noticing MHIS personnel at work on the wards. ${ }^{18}$

If a patient either asks to see a member of the MHIS (or simply a lawyer), or requests a court hearing, a member of the MHIS is notified and promptly contacts the patient. Because the offices of the MHIS are located within the hospital, the services of an experienced attorney are readily available to all patients. ${ }^{10}$ If, during the interview

13. N.Y. MeNtal HygIENe LaW \& 31.27 (McKinney 1973).

14. Id. § 31.31 .

15. Id. $\S 31.07(\mathrm{a})$.

16. Id. $\S 31.07(\mathrm{~b})$.

17. There is no requirement, however, that hospital personnel inform patients about the availability of counsel.

18. It may be argued that the presence of the Service and the notice and information it provides to patients will agitate many patients, make them resistant to treatment, or stir up needless litigation. There does not appear to be any substantiation of such charges, however, and most evidence appears to be to the contrary. See, c.g., Meyer, Lawyer in a Mental Hospital: The New York Experiment, 53 MeNTAL Hygiene 14, 16 (1969); Geller, The New Mental Hygiene Law, N.Y.L.J., June 8, 1966, at 4, col. 1.

The author's own experience (through observing and conducting many informational interviews) is that it is usually therapeutic for patients to know that there is someone interested in their rights, and that they have rights and recourse to the courts should they be committed against their wishes. Indeed, it is often quite surprising to discover the tremendous faith that incarcerated individuals place in the courts. Thus, knowledge of the availability of a judicial hearing is often a source of considerable reassurance.

Moreover, many of the patients informed by the author of the availability of legal assistance responded that they had neither the need nor the desire to contact counsel at the present time, but added that they were thankful for being informed of the availability of such services and would certainly consider obtaining counsel if the need ever arose.

19. Of course, a mere right to retain private counsel would be meaningless for the great majority of "mental patients" who are poor as well as disturbed, but it is also the case that

[t]he concept of free legal services only for the indigent has no place in civil commitment procedures. Even a person who may be able to retain a private 
that follows, the patient expresses a desire to be discharged, the MHIS attorney will note the patient's request and explain his or her status and rights. If the patient still wishes to leave, the Service member reiterates the patient's right to a hearing, but also suggests that the hospital's plans be determined first.

A conference with the patient's doctor follows. Often the doctor will inform the Service attorney that he or she plans to discharge the patient within a certain period of time, at least if the patient continues to improve. If this arrangement is satisfactory to the patient, no hearing is scheduled. Alternatively, the patient may agree to remain in the hospital as a voluntary patient. If the physician insists that the patient is in need of treatment, but the patient persists in requesting discharge, the MHIS attorney will explore with both parties the possibility of outpatient care. In most cases, the overburdened hospital staff is quite willing to work with the MHIS staff in seeking alternatives to hospitalization.

If no suitable compromise can be reached, a formal hearing is scheduled. At Bellevue, an MHIS attorney-almost always the same attorney who previously represented the patient-will be assigned as the patient's counsel for the hearing. The New York statute, however, also requires that the MHIS provide the court with a complete report on the patient's case. ${ }^{20}$ As will be seen, this requirement causes MHIS attorneys a number of difficulties in finding a proper role for themselves.

\section{III}

\section{ELEMENTS OF A StATE-SUPPORTED LegAL DeFENSE SYSTEM FOR Mental Patients: The New York Experience AND ITS IMPLICATTONS}

\section{A. Adequacy of Notice}

Patients will be able to utilize legal services effectively only if they are adequately informed of their availability. ${ }^{21}$ Unfortunately, providing "notice reasonably calculated under all the circumstances to apprise"22 patients of their rights is not always a simple matter. Providing patients with written notice of their rights upon adumission to a hos-

lawyer at his own expense is unable to do so once he is confined im a mental hospital. Most private lawyers are reluctant to represent mental patients because of the uncertainty of their being remunerated by the client's estate.

Gupta, supra note 10, at 446-47.

20. N.Y. Mental Hygiene LaW \& 29.09(b) (3) (McKinney 1973).

21. Cf. In re Barnard, 455 F.2d 1370, 1375 (D.C. Cir. 1971); Lessard v. Schmidt, 349 F. Supp. 1078, 1097-1100 (E.D. Wis. 1972), vacated and remanded for more specific order, 94 S. Ct. 713 (1974).

22. Mullane v. Central Hanover Trust Co., 339 U.S. 306, 314 (1950). 
pital is often an exercise in futility. Of the patients interviewed by the author-all of whom were sufficiently competent to be interviewed -none had any clear recollection of the contents of the written notice given to them when they were admitted, and most did not even remember receiving or reading it. Few of the recently admitted patients knew that lawyers were available in the hospital to assist them, and fewer still had any clear idea of their legal rights in seeking a discharge. These findings are not entirely surprising. As many patients themselves suggested, when individuals are brought to the hospital, few are in any emotional condition to understand anything they are told or given to read. ${ }^{23}$

Perhaps in response to the obvious inadequacy of written notice at the time of commitment, additional provisions for posted notice have recently been put into effect. ${ }^{24}$ It is unlikely, however, that posted announcements can supply adequate notice. The complex laws that define patients' rights often cannot be fully understood by individuals who are emotionally upset. Written notice is only a poor substitute for a personal interview in which questions can be answered and difficult points explained. ${ }^{25}$ Accordingly, MHIS tries to conduct an "information interview" with each patient shortly after his or her arrival. These interviews are conducted either by social workers or by MHIS attorneys. Another author's observation of a number of such interviews revealed significant differences in the way each group conducted them. Interviews by the legal staff resembled everyday dialogues between lawyer and client; the patient asked about his or her problem, and the lawyer responded with advice about his or her rights. The social workers, in contrast, tended to inform the patients of their legal rights by paraphrasing the statement of statutory provisions containcd in the hospital's notice; they showed little concern about whether the patients genuinely comprehended their rights and the reasons for their commitment. ${ }^{26}$ Many patients are passive or frightened individuals,

23. No doubt to some extent the patients' general lack of knowledge concerning their rights and privileges is a product of their emotional problems and confusion. However, it should be noted that the sample of interviewees consisted only of patients who could "understand" the questions and were willing to respond to them; i.e., they had at least a minimal degree of comprehension and emotional stability. Significantly, many patients, when informed by the author of the availability of legal assistance, clearly understood the meaning of, and expressed interest in, such assistance. In any event, to the extent that some patients may indeed remain for some time in, or relapse back into, a state of confusion, and to the extent that patients will differ in this regard, a flexible and manifold system of providing notice is required if it is to be truly effective.

24. N.Y. Mental HyGiene LaW \$ 31.07(b) (McKinney 1973).

25. See also Andalman \& Chambers, supra note 9, at 63-64.

26. Gupta, supra note 10, at 443; cf. Tancredi \& Clark, Psychiatry and the Legal Rights of Patients, 129 AM. J. Psychiatry 328 (1972). 
reluctant to exercise their right to counsel on their own initiative. They will be much more likely to exercise their legal rights if an attorney advises them that they do have rights and need not be afraid to exercise them. Indeed, a number of patients informed the author that they might be reluctant to contact a lawyer for fear of antagonizing their doctors-the individuals they believe to exercise the inost control over their future.

Thus, attorneys should not be assigned only to those patients who request a hearing. An attorney should meet with every patient to ascertain his or her attitudes toward hospitalization, and to explain the full range of his or her rights, especially the right to pursue alternatives to hospitalization. Waiver of the assistance of counsel should be considered valid only after the patient has been informed by an attorney of the availability and advantages of counsel. ${ }^{27}$ Although MHIS tries to notify each patient of the range of its services, its success is far from umiversal. After the patients interviewed by the author were informed of the availability of counsel, almost half indicated an interest in contacting an attorney.

Even when an attorney conducts the initial interview, the patient may not be effectively informed of his or her legal rights. As mentioned earlier, immediately after admission many patients are in no emotional condition to comprehend any notice of their rightswhether oral or wirtten. Some patients are so drugged that they cannot comprehend complex explanations. Other patients may be so eager to talk with anyone about their problems that the attorney cannot interrupt them without seeming rude or uncaring. Finally, legal personnel are sometimes too busy with more pressing tasks, such as preparing for hearings, to take time for preliminary interviews. ${ }^{28}$ For these reasons, attorneys slould not be required to interview every patient immediately upon admission to the lospital. Prompt notice is certainly a virtue, but many patients will receive better notice if they are interviewed a few days after admission when they are more receptive to a meeting with an attorney. ${ }^{29}$ Of course attorneys should meet with patients who request an interview as soon as possible, and the legal staff should be informed immediately of each admission.

\section{B. Initial Negotiation with the Hospital Staff}

The image of mental institutions as long-term warehouses of human neglect is rapidly receding before the demand that such facilities

27. See also Gupta, supra note 10, at 443-46. Regarding the possibilities of preadmission legal counseling, see $A$ New Approach, supra note 10, at 683-85 (1967).

28. See also Andalman \& Chambers, supra note 9, at 66-67.

29. See note 23 supra. 
provide each patient with an oppontunity for eventual recovery and return to normal society. Accordingly, decisions regarding the patient's course of treatment have begun to assume central significance.

Consultation between the patient's physican and attorney is often necessary for the formulation of a plan of treatment acceptable to the patient. Physicians are usually more willing to discuss these matters with attorneys, persons of their own professional and intellectual level, than with their often incoherent or agitated patients. Sometimes the attorney need only assert the patient's desire to be discharged, and the patient's willingness to go to court if necessary, to motivate the physician to develop an acceptable plan of treatment. Busy physicians frequently are unaware that the patient has improved sufficiently to be considered for discharge, or that alternatives to hospitalization have not been considered by the hospital staff. Such information can be of great importance in persuading the physician to discharge the patient. ${ }^{30}$

It is especially important that the responsibility for finding alternatives to hospitalization be allocated outside the hospital staff. Lowerechelon hospital personnel, im particular, cannot be relied upon to search diligently for alternatives, especially if their superiors believe the patient should remain hospitalized. For example, a social worker on the staff at Bellevue informed the author that she could not actively explore alternatives to hospitalization without the support of her superior who, like most physicians, rarely considered alternatives once he decided that the patient needed hospitalization.

Many lawyers, however, are not equipped to explore the social service resources of a community or the resources within the patient's family. At Bellevue, and elsewhere througliout the First Department,

30. There may be a constitutional right to have alternatives to hospitalization explored. Chambers, Aliernatives to Civil Commitment of the Mentally Ill: Practical Guides and Constitutional Imperatives, 70 MicH. L. REv. 1107, 1145-68 (1972) [hereinafter cited as Chambers]; see Covington v. Harris, 419 F.2d 617, 623 (D.C. Cir. 1969). Contra, State v. Sanchez, 80 N.M. 438, 441, 457 P.2d 370, 373 (1968), appeal dismissed, 396 U.S. 276 (1969); cf. Lake v. Cameron, 364 F.2d 657, 663 (D.C. Cir. 1966) (Burger, J., dissenting), cert. denied, 382 U.S. 863 (1966). The type of exploration involved is illustrated by Lake v. Cameron, 364 F.2d 657, 659-62 (D.C. Cir. 1966), cert. denied, 382 U.S. 863 (1966) (statutory right).

The availability of alternatives to hospitalization can also be very influential with judges. At the least, counsel should encourage the hospital staff to investigate alternatives and, if one is not discovered, question the testifying physician about this at the commitment hearing.

The New York Mental Hygiene Law requires that before a physician certifies a person as requiring hospitalization, "he shall consider alternative forms of care and treatment that might be adequate to provide for the person's needs without requiring involuntary hospitalization." N.Y. MENTAL HyGIENE LAW $\$ 31.27$ (d) (McKinney 1973). 
that problem is solved by including at least one social worker on the staff of each MHIIS unit. This enables counsel to conduct an independent investigation of alternatives to hospitalization and, if necessary, of the patient's social-familial history. ${ }^{31}$

There will still be instances, of course, when a physician will imsist upon indefinite hospitalization despite the availability of alternatives. In that case, the attorney's discussions should be aimed at ascertaining the basis of the commitment decision, ensuring that the hospital has considered all the alternatives to hospitalization and obtaining an appropriate and mutually acceptable treatment plan for the patient. If the commitment seems unjustified, the attorney should point this out to the physician. Although the lawyer cannot be expected to have a proficient understanding of psychiatry, he can insist that the psychiatrist use nontechnical language in describing the patient's condition and in supporting his or her recommendation of continued commitinent. Insistimg that the psychiatrist justify every such recommendation can reduce the tendency of doctors to recommend commitment in marginal cases. ${ }^{32}$ It can also cause hospitals to lengthen the observation period in such cases to ensure proper diagnosis.

After ascertaining the physician's views, the attorney may conclude that it is in the patient's interests to remain in the hospital for further treatinent or at least that the patient could not win release through a hearing at that time. If the latter, counsel might advise the patient that a scheduled hearing be postponed until he or she "improves" somewhat, in order to enhance the chances of being discharged. ${ }^{83}$

The importance of negotiated settlements cannot be overestimated. Not only is the result one which is acceptable to both patient and doctor, it also obviates the need for a time-consuming and often unpleasant hearing. Moreover, there is evidence that judges tend to be conservative in their rulings-that, on the average, they require a lower level of pathology for commitment than psychiatrists. ${ }^{34}$ Indeed, it seems likely that many patients who are discharged through the

77.

31. See Cohen, supra note 2 , at 452 . See also Chambers, supra note 30 , at 1176 -

32. See Broderick, supra note 10, at 626 n.366.

33. R. Janopaul, Problems in Hospitalizang the Mentaliy Ill 13-14 (American Bar Foundation Research Memorandum Series No. 31, 1962).

In short, while the attorney must ultimately represeut a client's wishes, this in no way detracts from his traditional duty to counsel the client, though the attorney, especially in this area, must also remain aware of his or her own paternalistic tendencies and the limitations of his or her ability to discern what is indeed the best course of action for the client.

34. Kumasaka, Stokes \& Gupta, Criteria for Involuntary Hospitalization, 26 ARCHIVE OF GENERAL PSXCHIATRY 399, 402 (1972). 
negotiating process would have remained hospitalized if their cases had come before a court. Effective legal representation, in short, requires considerable activity on the part of counsel prior to any judicial hearing. ${ }^{35}$

It should be clear from what has been said already that adequate representation of involuntarily committed patients can only be provided by a knowledgeable, full-time legal staff ${ }^{36}$-ideally, one which is situated in the hospital itself. Such an arrangement allows for proinpt and frequent contact between counsel and patient, which in turn facilitates full discussion of how best to protect the patient's interests. It also allows for extended negotiations with the patient's doctor. Finally, it fosters the patient's confidence in the attorney and increases the patient's willingness to assert his or her rights.

The close relationships that often develop at Bellevue between MHIS attorneys and their clients are striking, especially when contrasted with those between patients and attorneys appointed on a sporadic basis. Appointed attorneys usually lack the time or inclination to take an active interest in the patient's case. They are less likely to imvestigate alternatives to hospitalization, and rarely have the expertise to negotiate with psychiatrists. They also may be reluctant to argue the patient's case as forcefully as possible, for fear of jeopardizing future appointments. ${ }^{37}$ Only full-time advocates are likely to develop a commitment to the rights of emotionally disturbed individuals. Understanding and empathy for the emotionally disturbed are not likely to develop from sporadic appointments.

Indeed, in the Second Department, where MHIS attorneys do not represent patients, the attorneys take a more paternalistic attitude. Researchers have found that First Department MHIS lawyers consider involuntary hospitalization either dispensable altogether, or necessary only in very few cases, while Second Department lawyers, along with most Bellevue psychiatrists, accept it unquestioningly ${ }^{38}$ First Depart-

35. It has been suggested that counsel may also serve such extra-hearing functions as challenging hospital rules that unnecessarily curtail the patient's freedom, guarding the patient against the schemes of conspiring family members, and protecting easily-swayed individuals from the influence of misinformation. Sec Harris, Mental Health, Due Process and Lawyers, 55 A.B.A.J. 65, 66 (1969).

36. On the importance of full-time counsel, see id. at 54, 72-74, 80-82.

37. Any system which provides for a full-time legal staff with supporting services, to represent individuals threatened with civil commitment will necessarily entail substantial expenditures. Whether such a system is more costly than one utilizing private attorneys, however, is questionable. Cost-benefit studies certainly need to be done. For a preliminary discussion, see Andalman \& Chambers, supra note 9, at 80-84.

38. Kumasaka \& Stokes, Involuntary Hospitalization: Opinions and Attitudes of Psychintrists and Lawyers, in Kumasaka, Gupta, Stokes \& Sharma, Final Report: Evaluation of the Mentally Ill-Civil Commitment Problems, part E, May 1971, at 3 (un- 
ment attorneys tend to see involuntary hospitalization in terms of protecting the individual patient; Second Department attorneys, in terms of protecting the community. First Department attorneys also tend to find "dangerousness" a relatively unhelpful criterion for hospitalization, justifying at most only short-term commitments; Second Department lawyers and psychiatrists, in contrast, find it quite useful. First Department MHIIS attorneys either believe "dangerousness" to be an entirely useless standard, or one that can be applied only in light of the patient's entire case history. Second Department attorneys, on the other hand, almost unanimously accept it as a standard that can be applied without substantiating evidence, a view that permits broad scope for psychiatric discretion. ${ }^{39}$

It may be that the expressed attitudes of MHIS attorneys in the First Department did not result from their full-time role-in court and out-as advocates of patients' interests. It may be that MHIS personnel choose the job, and are chosen, because they already possess these attitudes. It is more likely, lowever, that a professional commitinent to representing mental patients, fostered by supervisors who expect forceful representation, las produced the aggressive and effective advocacy of First Department attorneys. ${ }^{40}$

Second Department attorneys seem to develop more neutral attitudes. They view their role as largely confined to implementing a statute that provides, among other things, for involuntary hospitalization. A Second Department lawyer who rejected the idea of involuntary hospitalization might find it difficult to perform the duties required of lim or lier. On the other liand, a lawyer who is expected to function as a neutral figure is likely to develop attitudes supporting and justifying that role.

\section{The Role of the Attorney at Court Hearings}

An attitude of respect for the patient's wishes is especially necessary for adequate representation of the patient in court. No attorney would disagree with the proposition that counsel must argue for the ends desired by the client to the best of his or her ability. ${ }^{41}$ Coun-

published report funded by National Institute of Mental Health, Public Health Service Grant MH 16485).

39. There is considerable evidence that the attitude of First Department MHIS attorneys toward the concept of "dangerousness" is fully justified. See Ennis \& Litwack, Psychiatry and the Presumption of Expertise: Flipping Coins in the Courtroom, 62 CaLIF. L. Rev. 693 (1974) (this issue) [hereinafter cited as Ennis \& Litwack].

40. Personal conversation with MHIS attorneys at Bellevue suggests that one of the reasons for their relatively militant position is that their constant contact with psychiatrists and psychiatric judgments has greatly diminished their respect for both. Certainly there is no presumption on their part that the "doctor knows best."

41. This requirement is founded on the Constitution as well as on professional 
sel should clarify and fully explore all relevant issues. ${ }^{42}$ This requires an adversarial-though not necessarily hostile-stance toward the parties seeking to restrict the client's liberty. ${ }^{43}$

ethics. The Supreme Court has recognized:

[T] The constitutional requirement of substantial equality and fair process can only be attained where counsel acts in the role of an active advocate in behalf of his client, as opposed to that of amicus curiae.

Anders v. California, 386 U.S. 738, 744 (1967). Arguing from the requirements of the canons of legal ethics, one attorney has concluded:

[A]lthough [the attorney] should be a counsellor and negotiator in the prehearing stages, he must be an adversary in the courtroom, for no other role there seems possible. Naturally, different tactics and emphases will suggest themselves in accordance with counsel's estimates of the truthfulness of witnesses, the validity of diagnostic and prognostic data, and the likelihood and feasibility of various dispositional alternatives. But such variables occur in all litigation, and do not vitiate the lawyer's basic role as a partisan conbatant. It is not his responsibility to decide the "best interests" of the community, or whether the client is dangerous to himself or others, but rather to present effectively the client's side of the case, so that the court may make an informed judgment on these issues.

Blinick, Mental Disability, Legal Ethics, and Professional Responsibility, 33 ALBaNY L. REv. 92, 115 (1968) (emphasis in original).

For a discussion of certain technical problems, such as challenging hearsay and opinion evidence and deciding whether the client should testify, involved in representing individuals at civil commitment hearings, see Galter, The Role of Defense Counsel in Civil Commitment Hearings, 10 AM. CRIM. L. REv. 385 (1972); ZISKIN, supra noto 7; Note, How to Represent Clients at Mental Commitment Hearings, 23 LEOAL AID BRIEF CASE 19, 20 (1964). A difficult question is whether an allegedly mentally ill person has a right to waive the right to counsel. See Note, The Riglit to Counsel at Civil Competency Proceedings, 40 TEMP. L.Q. 381, $390-92$ (1967).

42. Kumasaka and Gupta discovered in a study of Bellevue commitment hearings that the following issues tended to arise between the patient's attorney and the testifying psychiatrists: whether there was evidence of dangerousness; the probability of dangerous behavior in the future; how well the patient was "functioning" and whether any indications of "poor" functioning were due to the patient's social situation or to "mental illness"; whether there was any useful purpose to hospitalization; whether the "benefit of a doubt" should favor release or commitment; and whether the patient had recently been exhibiting "abnormal behavior" or behavior that was a product of hospitalization. Kumasaka \& Gupta, supra note 7, at 10-31.

There is much evidence that a patient's socio-economic status may have considerable effects on psychiatric decisions to commit. See Ennis \& Litwack, supra note 39, at 724. To the extent that socio-economic variables are favorable to a decision to discharge in a particular case, the attorney should bring them to the attention of the physician and/or the court. To the extent that, in other cases, the patient's low socioeconomic status will tend to prejudice judicial and psychiatric decisions against discharge, the attorney must make the court and the hospital personnel aware of whatever subtle biases might be operating.

43. A bill which seeks to provide the MHIS with statewide "specific responsibility for representation of patients and advocacy of their rights, including their rights in aftercare," and which would "prohibit the [MHIS] from acting in any manuer in which its legal responsibilities to a patient and its duty to report to the court may be ethically or legally inconsistent," has recently been introduced. Memorandum in Support of A. 11101, S. 9200, N.Y. Legislature, 1974 Sess., at 1. According to the Memorandum, furnished to the author by the office of Assemblyman Robert C. Wertz, workshops and conferences conducted by the Assembly Subcommittee on Mental Hy. giene "pointed to the need for the MHIS to assume [an] active advocacy role on be- 
Nevertheless, studies of representation in Arizona, Texas, and other jurisdictions ${ }^{44}$ reveal that individuals subject to civil commitment proceedings are rarely provided with counsel who strive to discover and advocate the ends that they desire. ${ }^{45}$ Even more rarely is a patient provided with pre-hearing services of counsel-an indispensable prerequisite for protecting the patient's interests. Inadequacy of representation also results from what has been called the problein of "rolelessness." 46 Unless they are members of a full-time staff of specialists, attorneys in civil commitment proceedings rarely see their chents prior to the commitment hearing. They therefore develop litthe sense of identification with their clients. More fundamentally, however, they are often uncertain about what they wish to accomplish. Unlike criminal defense attorneys, who can be sure that release is in the best interests of their clients-whatever its effects on societyattorneys assigned to represent the allegedly mentally ill are often genuinely unsure what is best for their clients. Indeed, they may often see their role as assisting the hospital in obtaining commitment.

Perhaps one reason for this uncertainty is the different perceptions that attorneys have of imprisonment and hospitalization. While few attorneys believe that imprisonment will be in any way beneficial for their clients, many may wrongly assume that hospitalization is always beneficial for the "mentally ill." More awareness of the many well-documented similarities between incarceration in a prison and incarceration in a inental hospital could greatly reduce this uncentainty.

Attorneys also may often be unsure, at least on an emotional level, who their clients are. Appointed attorneys, after all, are selected by the court and, in inost cases, the attitude of the court is clear: it does not expect attorneys to represent their patient-clients in the traditional legal manner. The number of cases on the docket for each

half of the mentally disabled and the alleged mentally disabled in addition to its other responsibilities, and the need for a name change to accentuate that new role." Id. at 2. Accordingly, the bill proposed to change the name of the MHIS to "Mental Health Legal and Information Service."

44. Andalman \& Chambers, supra note 9, at 54-72.

45. A recent study of civil commitment procedures in Wisconsin noted the difference between the attorney as guardian and the attorney as representative. The study concluded:

In present practice, it seems clear that in almost all cases where a guardian is appointed he sees his role not as au advocate for the prospective patient but as a traditional guardian whose function is to evaluate for himself what is in the best interests of his client-ward and then proceed, almost independent of the client-ward, to accomplish this.

Dix, Hospitalization of the Mentally Ill in Wisconsin: A Need for a Re-examination, 51 MARQ. L. Rev. 1, 33 (1967). 446-50.

46. For an early discussion of this phenomenon, see Cohen, supra note 2, at 
day make it painfully apparent that anything even approaching a meaningful hearing for more than a very few patients would destroy the system of rapid, and more or less predetermined, commitment proceedings.

Another element contributimg to inadequate representation is the fact that attorneys are likely to feel unqualified to question medical and psychiatric judgments and testimony. Many attorneys are unaware of the limitations and fallibility of psychiatric determinations, ${ }^{47}$ which they regard as statements of objective medical fact. Understanding psychiatric reasoning and jargon - and knowimg how to cross-examine expert psychiatric witnesses-requires considerable experience and skill. ${ }^{48}$ Furthermore, inadequate financial resources and lack of time can deter attorneys from seeking imdependent psychiatric examinations or advice. ${ }^{49}$

That the proceedings are often not clearly adversarial in nature further confuses the attorney's attempt to ascertain his or her role. Frequently the committing party is not represented by counsel. The absence of an opponent is an unnerving experience for attorneys who have been trained to see theinselves as legal strategists. Negotiation and competitive advocacy are skills attorneys understand. But the exercise of these skills requires a well-defined adversary. Lacking an opponent to outmaneuver or challenge and a clear idea of what constitutes success, lawyers often find themselves unable to perform any meaningful function in commitment proceedings.

Furthermore, patients are often too passive, frightened, or heavily medicated to articulate their wishes forcefully, while their assigned attorneys are usually unaccustomed to inquiring what their clients want. Even if such inquiries are made, however, patients will often be in no position to answer because, like their attorneys, they are unaware of the available alternatives. ${ }^{50}$ Thus, attorneys often see their

47. See Ennis \& Litwack, supra note 39; and Leifer, The Competence of the Psychiatrist to Assent in the Determination of Incompetency: A Skeptical Inquiry into the Courtroom Function of Psychiatrists, 14 SYRAcuse L. Rev, 564 (1963).

48. Andalman \& Chambers, supra note 9, at 50.

49. In a criminal case in which the insanity defense had been raised, such neglect clearly would constitute inadequate representation. Cohen, supra note 2, at 450 . Nor do attorneys typically exhibit such deference to psychiatric judgments in tort actions, will contests, and the like. Thus, it is not merely inexperience with psychiatric testimony that makes for snch deferential behavior on the part of attorneys, but rather other conflicts about their role and perhaps about the mentally ill as well.

The author has heard judges say from the bench that they think psychiatry is "a lot of gobbledygook," adding, however, that they had no choice but to go along with the psychiatric judgments.

Perhaps truly adequate representation can only be obtained if counsel has available the services of independent psychiatric examiners-reimbursed by the state if necessary.

50. In certain ways individuals subject to civil commitment proceedings require 
role in commitment proceedings to be one of inerely guarding the procedural rights of the patient. ${ }^{51}$

But perhaps the most pervasive influence of all is the reluctance of some attorneys to advocate their clients' wishes actively for fear of appearing foolish before the court. The attorney in a civil commitDient proceeding may very well be representing a patient who appears in inanner, dress, and speech to be "inentally ill" to others, including the judge. Yet the attorney inay feel that adequate representation requires an argument that the patient is not "mentally ill." In sucl a situation, the attorney may feel embarassed to argue for a proposition directly contradicted by evidence visible in the courtroom itself and often corroborated by "expert" opinion. In a criminal proceeding, by contrast, all the relevant evidence is, in a sense, indirect; the jury has not observed the crime. Nor is the jury permitted to hear expert testiinony regarding the defendant's criminal propensities. Rather, the evidence is usually in the form of lay testimony about past events. Therefore, defense counsel rarely feels the embarassment of arguing against what appears to be a self-evident proposition, or one based largely on "expert" opinion.

However, such a dilemma can be avoided in commitment proceedings. The attorney need not argue that the client is not "inentally ill' if indeed the client's manner and behavior, and the strength of the psychiatric testimony, make that position untenable. ${ }^{52}$ Other equally effective arguments can be made instead. For example, the attorney can contend that the patient is not dangerous, is not in need of hospitalization, or would benefit nore from an outpatient program. Moreover, the attorney can always challenge psychiatric testimony to the contrary, since issues regarding future events will rarely be clearcut and will necessarily involve uncertain predictions.

\section{Role Problems in the MHIS}

One might expect, given the system of coinprehensive, full-time representation established by the MHIS in the First Department, and

more active services from counsel than do criminal defendants. For one thing, the criminal defendant is less likely to be disturbed, and more likely to be articulate. For another, the criminal defendant is expected to provide much of the information-such as alibis-the attorney will need, and the basic issue is usually a rather clear-cut one. In civil commitment proceedings, on the other hand, there is no clear way for the patient to estabhish his sanity, and the most important evidence may be data-such as alternatives to hospitalization-about which the patient-client cannot be expected to have any knowledge. Certainly the patient-clieut cannot be expected to aid the attorney in his cross-examination of psychiatric judgments and predictions.

51. Project, supra note 5 , at 53 .

52. The attorney, of course, must guard against the influence of value judgments about the patient's behavior masquerading as medical diagnosis. 
given the professional attitudes this system both attracts and develops, that First Department MHIS attorneys would be relatively free of the problems of "rolelessness" described above and correspondingly free to assume a forceful adversarial posture at commitment hearings. Somewhat surprisingly, this is only partly the case.53 Many Bellevue commitment hearings are not especially adversarial in nature, even though the lawyers and psychiatrists involved may appear, in some cases to engage in strenuous debate. MHIS attorneys provide forceful representation in cases where they feel the patient should and may be released by the court, but they provide weaker representation in less hopeful cases. ${ }^{54}$

As discussed above, MHIS attorneys often develop a sense of identification with their chents and, at least when they believe a case has merit, feel free to advocate vigorously their clients' wishes. Certainly they do not feel that either the court or the MHIS expects them to rubberstamp psychiatric determinations. Nor do these attorneys have much difficulty viewing the testifying psychiatrist as their adversary. Indeed, the frequent contact of MHIS attorneys with hospital psychiatrists leaves them quite skeptical about psychiatric judgments and terminology. Moreover, unlike many appointed attorneys, they have enough time to prepare their cases and to explore and present alternatives to hospitalization.

Nevertheless, the author's own experience is that MHIS attorneys tacitly decide how "well" or "sick" a particular client is-and how much the client needs hospitalization-and then adjust their efforts at representation accordingly. Perhaps such tacit and possibly subconscious determinations are unavoidable. After all, patients who may benefit from extended hospitalization may be the least capable of making a reasoned decision about their own best interests. It may be asking too much of attorneys who care about their clients to expect them to forcefully advocate discharge when they believe it would be harmful. On the other hand, attorneys representing even obviously disturbed patients must realize that their ability to determine what is in their clients' best interest or to predict the future is extremely limited. In any event, it is not their function to make such decisions. Indeed,

53. See Kumasaka \& Gupta, supra note 7.

54. See Andalman \& Chambers, supra note 9, at 62; Gupta, supra note 10, at 437; Kumasaka, supra note 10, at 26-28. Kumasaka's evidence suggests that MH1S attorneys at Bellevue forcefully represent the patient-client's wishes in only a minority of cases, and in some cases even "recommend," though not overtly, hospitalization. The same study also suggests that when MHIS attorneys "fight" for discharge they are quite successful and, conversely, when they do not, the patient is almost certainly committed. It is difficult, however, if not impossible, to separate the influence of the attorneys's efforts (or lack of them) and that of the patient's condition at the time of the hearing. See, e.g., Andalman \& Chambers, supra note 9, at 69. 
if a patient is clearly in need of continued hospitalization, that conclusion should become apparent to the court-despite forceful advocacy to the contrary by the patient's attorney.

But aside from paternalistic tendencies, MHIS attorneys are also afflicted with a fear of appearing foolish. Even the most ardent advocate may shrink from the prospect of arguing for the discharge of a patient who is unable to control his or her behavior in the courtroom or who has delusions of persecution. Indeed, even an attorney who beheves that such behavior is not a sufficient basis for hospitalization ${ }^{55}$ will hesitate to argue the case before a judge, who almost certainly beheves otherwise, for fear of losing the judge's respect.

\section{The Requirement of a Complete Report}

A related role problem often arises from the statutory mandate that the MHIS "assemble and provide the court with all relevant information as to the patient's case, his hospitalization, [and] his right to discharge, if any." ${ }^{\circ 6}$ In the First Department these written reports are, in effect, submitted by the patient's own counsel. They are based upon information from the patient's records and from extensive interviews with the patient, the hospital staff, and perhaps the patient's family and friends. ${ }^{57}$ These reports are given considerable weight by judges, who regard them as relatively objective, even when they are written by the patient's attorney. They supply judges with the infor-

55. For instance, because he or she believes that having delusions of persecution is far removed from acting upon them.

56. N.Y. MENTAL HYGIENE LAW $§ 29.09$ (b)(3) (McKinney 1973).

57. In the First Department, reports are expected to cover the following subjects:

1. The nature of the proceedings.

2. Legal representation.

3. Events leading to hospitalization.

4. Dangerousness of patient-to hinself or to others (including the basis for this characterization by the patient's physician).

5. Personal history.

6. Education, work background and resources.

7. Medical history, both psychiatric and other.

8. Present psychiatric diagnosis.

9. Date seen by hospital doctor.

10. Staff interviews with the patient, his doctor, social worker and family and others.

11. Other pertinent information.

12. Hospital's recommendation.

13. Alternatives to commitment: (a) Explored by hospital; (b) explored by the Service; (c) appropriate to the case.

14. Patient advised of his or her rights.

15. A suminary stating: a) the patient's position or contentions; b) the hospital's position or contentions.

Revised Operating Procedure No. 2; Mental Health Information Service, First Judicial Dep't (April 7, 1970). 
mation necessary for an informed decision, but they also prevent commitment proceedings from becoming a purely adversarial contest between the testifying psychiatrist and the patient's counsel. Paradoxically, the neutral character of the report often enhances the patient's chances for discharge, since judges are reluctant to rule against the opinions of psychiatrists unless they feel they have some objective basis for doing so. ${ }^{58}$

Nevertheless, the requirement of a complete report raises serious due process problems. Can an attorney who has the duty of providing the court with "all relevant information as to the patient's case" adequately serve as that patient's counsel? This dual role raises the possibility of a serious conflict of interest. ${ }^{58}$

In practice, however, the tendency toward divided loyalty is slight. In fact, it is very unlikely that a system of unrestrained advocacy would result in a greater number of judicial discharges than are presently ordered. Since MHIS attorneys are perceived by judges as neutral, even expert, advisors to the court, they undoubtedly exercise much greater influence than they would if perceived as exclusively partisan advocates. The evidence indicates that an MHIS recommendation of discharge is usually followed. ${ }^{60}$ Patients for whom the Service advocates discharge less forcefully are perhaps disadvantaged by this system, but they probably would be committed regardless of the anount of effort expended by their counsel. ${ }^{61}$ Although many such patients inay clearly require hospitalization, the borderline patients for whom it is not clear whether discharge or commitunent would be better are undoubtedly disadvantaged by the present system. Once a patient's own counsel files an unfavorable report, any effective challenge to the commitment order becomes impossible.

58. A former Presiding Justice of the First Judicial Department has observed:

Mntroducing legal assistance into the MHIS program did not detract from the value of a neutral report ..... I remcmber the time when if the doctor had the slightest doubt, the person could be confined. The judge had no more information than that, and he was not going to take the chance.

Interview, Jan. 1970, reported in Broderick, supra note 10, at 626 n.366.

59. Andalman \& Chambers, supra note 9, at 66 n.99.

60. See note 54 supra. MHIS attorneys have indicated to the author that their position as agents of the court also allows them to be much more effective in their dealings with private agencies and institntions than if they only were the patient's private attorney.

61. Indeed, it is entirely possible that without the reports, and with a purely adversarial system, fewer patients would be released by the courts in the First Department than is presently the case. There is no empirical evidence, however, that the mere presence of competent and active counsel would be less effective than the present system. Moreover, whatever the merits of the present system in its present context, a purely adversarial system might be more effective at such time as the courts are more solicitous of patients' rights and less deferential to psychiatric opimions. 
The requirement of an impartial report also affects the way MHIS attorneys perceive their role vis-a-vis the court and their clients. They are quite aware that judges perceive them as sources of quasi-expent opinion. Thus, they may avoid advocating the discharge of obviously disturbed patients in order to maintain their image of expertise with the court. While the MHIS reports no longer specifically recommend discharge or lospitalization, when an MHIS attorney indicates-by the tone and forcefulness of a report-that a patient should be discharged, the judge often finds it persuasive. In order to maintain this influence, MHIS attorneys do not represent questionable cases as forcefully as they might. Instead, they attempt to preserve their image as nettral, objective observers for those cases where their clients liave a reasonable chance of discharge. While this strategy of conserving credibility may well maximize the total number of judicial discharges, it certainly works to the detriment of patients in more doubtful cases. ${ }^{62}$

The difficulties caused by the attorney's dual role cannot be easily overcome, especially since it is doubtful that any state would allocate substantial funds to an agency that did not serve some neutral administrative role. ${ }^{63}$ Some measures, lowever, can be taken to minimize the adverse impact of the attorney's conflicting roles on the patient. For one, patients can be clearly informed, pursuant to statute or rule of court, of the Service's responsibilities to the court, and they can be offered the alternative of obtaining counsel from legal aid. A special branch of legal aid could be trained for just this purpose. ${ }^{64}$

Another possibility would be to divide the functions of authoring reports and representing patients between different members of the MHIS staff. A certain number of attorneys could be designated to represent patients at hearings, but never to prepare the Service's reports to the court. These litigating attorneys would then be free to

62. While the problem of maintaining credibility is perhaps accentuated by the MHIS attorney's reporting function, it would seem to pertain to any system of representation for the allegedly mentally ill in which the same attorneys-or even different attorneys from the same staff-consistently represent patients before the same judges. Andalman \& Chambers, supra note 9, at 63, 82. It should be remembered, however, that a system of representation utilizing the ad hoc appointment of private attorneyseven assuming a stauce of active advocacy on the part of counsel-might well result in fewer judicial discharges than a system in which counsel has some credibility with which to counter "expert" psychiatric testinony.

63. But see Andalinan \& Chambers, supra note 9, at 52, 80-82.

64. Perhaps the MHIS should be required to trausfer to legal aid any patientclients they feel, for whatever reasons, they cannot represent adequately. In New York City, at least, there are attorneys who specialize in representing defendauts at competency-to-stand-trial hearings. In instances of personal incompatibilities, a patieut may be satisfied by simply having another staff attorney assigned as counsel. Conversely, lawyers should be sensitive to the possibilities that they might be so upset or frightened by a particular patient's pathology that the chient might be better represented by another attorney less disturbed by the problems the patient presents. 
conduct themselves solely as the patient's representative, even to the point of challenging the validity or relevance of any information included in the MFIIS report. In any staff of lawyers, some attorneys are better litigators than others, and such a division of labor could capitalize on the special aptitudes and interests of attorneys already employed by the MHIS. ${ }^{65}$

Also, the New York statute could be amended so as to continue the MHIS as counsel for patients subject to involuntary commitinent but to permit the Service to provide the courts with a report containing only such information as the Service feels might be useful to the court in its determination. Then the Service would no longer be an arm of the court but would still be able to place relevant information before the court, somewhat in the manner of an amicus. ${ }^{08}$

Such a modification of the Service's statutory mandate might lead to the courts' viewing the Service more as an adversary to the hospital and giving its reports less weight. However, just as the Service's reports are considered trustworthy in the First Department, despite the Service's role of advocate, so might the courts contimue to regard these "amicus reports" as useful and honest, even if they had to rely on the hospital to balance the picture with its report. Certainly, it would not be in the interest of a legal agency, constantly before the court, to mislead judges and thereby earn their distrust. The Service's need to remain a valued source of information should guarantee that its reports be objective and fair.

Another possible problem is that allowing the MHIS to provide patients with counsel might interfere with its relationships with hospital personnel, or conversely, that the Service's desire to maintain good relations with the hospital staff might interfere with adequate representation of patients-for example, by discouraging vigorous crossexamination of psychiatric testimony. In spite of the obvious potential for such conflicts of interest, the realities of the situation suggest that an adversary role for MHIIS attorneys need not necessarily reduce their rapport with the hospital staff. To begin with, the Service's reporting function may produce conflict with the hospital staff anyway, for the report, if conscientiously prepared, will often contain conelusions different from those reached by the hospital. Moreover, the advice which the Service dispenses will often lead patients to take actions which the hospital staff finds troublesoine. In short, there is an inherent tension between the hospital and the MHIS in any statutory ${ }^{r}$ role, and observation of many conferences between MHIS attorneys and hospital personnel suggests that serious conflicts are much more

65. Cf. Andalman \& Chambers, supra note 9, at 70 n.118.

66. See note 43 supra. 
a function of the personalities involved than of the role of the attorneys. Indeed, it appears that negotiated outcomes are facilitated by having the MHIS serve as the patient's counsel simply because it gives the Service some sanction-the threat of a court hearing - in the negotiations.

The problem of divided loyalties, however, is not limited to the requirement of an impartial report. It also colors the attorney's defense at the hearing or trial. Because the attorneys are employed by the state, they cannot help but be aware that the Service cannot continue to exist if it creates an intolerable situation for the government that sponsors it. Therefore, while Service attorneys are committed to effective advocacy, there is also a largely unconscious recognition of a limit to how far such representation will be accepted.

The clearest example of this syndrome is that once a patient is committed at a court hearing, counsel very rarely request a jury trial, to which evey patient has a right under the statute. Many MHIS attorneys justify their refusals to request jury trials by suggesting that most patients would be released by the time a jury trial took place; that any patient whom a judge refused to release would not be released by a jury either; that a jury trial might be traumatic for some patients; or that a judicial hearing sufficiently serves the patient's interests. These explanations all have inerit. But it is not the fact of a jury trial but rather the threat of one that is likely to result in a patient's discharge. The pressure put on the system by a large number of requests for jury trials would probably result in more negotiated outcomes-just as it does in the criminal system-and in fewer commitments. If an impending jury trial proved disturbing to a client, the request for such a trial could always be withdrawn. Indeed, it is hard to see how a patient's interest in discharge could possibly be harmed by the threat of a jury trial-yet, significantly, rarely are patients even informed of their right to a jury trial. The conclusion is thus inescapable that attorneys do not want patients to request jury trials, and sometimes feel that hospitalization would do them good. Such determinations, of course, are simply not proper for counsel to make unilaterally.

In any event, even after the decision to commit the patient-client has been made by the court, and even if that decision is acceptable to counsel, the duties of counsel continue. First, counsel should seek to insure that the client is placed in an appropriate and not excessively restrictive facility. Second, counsel should see to it that a treatment plan is formulated for the patient and carried out, that the client's condition is periodically re-examined, and that alternatives to hospitalization are contimually reviewed. Obviously, it is unrealistic to expect 
the patient's original attorney to continue performing all these services, especially if the patient is sent to another facility. Such responsibilities can be adequately discharged only by an in-hospital staff led, but not necessarily entirely staffed, by attorneys, at each major psychiatric facility. Indeed, only a state-wide, centralized organization of fulltime, in-hospital patient representatives can meet their chents' continuing legal needs. ${ }^{67}$

\section{CONCLUSION}

Both as a constitutional imperative and as a inatter of legal ethics the right to counsel should include each of the following elements: ${ }^{88}$

(1) Individuals subjected to civil commitment proceedings should receive adequate notice of their right to counsel. Adequate notice will generally involve oral notice delivered by someone schooled in the relevant law and committed to patients' rights. While such notice should be delivered to the client as soon after admission to a mental liealth facility as is practicable, it must not be delivered before the chent can clearly understand it. In some cases, this will be a considerable time after admission. Also, the duty to provide notice should not be considered discharged by a single, perfunctory recitation; rather, the attorney should assume responsibility for keeping clients contimually aware of their rights.

(2) Counsel should have the affirmative obligation of investigating the client's case and exploring alternatives to hospitalization. Ideally, counsel would be aided in this searcl by ancillary investigative personnel. With the background knowledge thus obtained, counsel

67. The full possibihties of in-hospital legal services also remain to be explored. Gupta has suggested that the MHIS be staffed to provide comprehensive legal service for hospitalized individuals. Gupta, supra note 10 , at 447 . Perhaps, too, the MHIS should perform an ombudsman role within psychiatric hospitals-investigating patients' complaints, arranging for their remedy if possible, forwarding justified but unremedied complaints to the appropriate authorities. See Broderick, supra note 10, at 637-44. Another role is bringing test cases to ensure that patients are receiving their rights under law and under the Constitution. E.g., Wyatt v. Stickney, 325 F. Supp. 781 (M.D. Ala. 1971) (treatment inadequate but ruling reserved to allow state officials opportunity to promulgate and implement standards); 344 F. Supp. 373 (M.D. Ala. 1972); (court withholds appointment of master); 344 F. Supp. 387 (M.D. Ala. 1972) (prompt institution of minimum standards ordered).

Article 15 of the New York Mental Hygiene Law guarantees to each patient a whole host of rights, including the right to "receive care and treatment that is suited to his needs and skillfully, safely, and humanely administered with full respect for his dignity and personal integrity." N.Y. MeNTaL Hygiene Law $\$ 15.03$ (a) (McKinney 1973).

68. A recent comprehensive survey of the systems of representation in eight states has come to many of the same conclusions expressed herem. Andalman \& Chambers, supra note 9 , at 50-52, 75-86. 
should discuss the case with the client's physician. Such discussion should be aimed at ascertaining the intentions of the hospital staff, the bases of any decision to commit, and the hospital staff's knowledge of any alternatives to hospitalization. Finally, counsel should negotiate with the client's physician a treatment plan mutually agreeable to the chent and the hospital.

(3) After negotiations with the client's physician, counsel should explain the situation to the client and present the available legal alternatives. Such a discussion should include an explanation of the hospital's plans, the likely outcoine of a hearing, and counsel's view of the best course of action for the chient.

(4) At any liearing or trial, counsel must represent the chent, and the client's wishes, to the best of his or her ability. This means effectively presenting the client's case, exploring and clarifying all relevant issues, and challenging adverse psychiatric judgments. Obviously, this dictates an adversarial-though not necessarily lostile - stance toward parties seeking to curtail the client's liberty. Indeed, the prospect of facing articulate and challengimg questioning at a hearing will encourage more thoughtful and deliberate handling of cases by psychiatrists.

It hardly needs restating that such a system of effective representation almost centainly requires a staff of full-time, in-hospital, patient representatives, such as are provided by the MHIS in New York's First Judicial Department. In addition, such attorneys can best perform their duties if they have the assistance of social workers in the investigation of clients' histories, socio-economic situations, and suitabilities for various alternatives to hositalization.

Only full-time patient advocates can be expected to have the time, the expertise, the relative freedom from governmental pressures, and the sense of commitment to adequately represent clients who are likely to be poor, disturbed, and otherwise alone in defending their rights. 